\title{
Effects of fibrin sealer and resorbable gelatin on the repair of osseous defects in rat tibia
}

\author{
Efeitos de selante de fibrina e de gelatina \\ absorvível no reparo de defeitos ósseos em \\ tíbia de rato
}

\begin{abstract}
Eleny Balducci Roslindo(a) Naiana Vianna Viola ${ }^{(b)}$ Ana Maria Minarelli Gaspar(c)
\end{abstract}

(a) PhD, Associate Professor; (b) Graduate Student; (c) PhD, Assistant Professor - Department of Morphology, School of Dentistry of Araraquara, State University of São Paulo.

\section{Corresponding author:}

Eleny Balducci Roslindo

Faculdade de Odontologia de

Araraquara - UNESP

Rua Humaitá, 1680,

Araraquara - SP - Brazil

CEP: 14811-903

E-mail: eleny@foar.unesp.br

\begin{abstract}
Gelfoam ${ }^{\circledR}$ - a biologically resorbable gelatin sponge - has the function of restricting hemorrhage, providing platelet rupture, and supporting fibrin threads. Beriplast $^{\circledR}$ - a fibrinogen-thrombin compound - is used to adhere tissues, to consolidate sutures and in hemostasis. The objective of this study was to perform a histological analysis of the effects of haemostatic agents on osseous repair. These materials were inserted into surgical sites in young rat right and left tibiae. After the observation periods of 7, 14, 30 and 45 days, according to the bioethic protocol, the animals were killed, the tibiae were removed and fixed in $10 \%$ formalin and decalcified in equal parts of formic acid and sodium citrate solutions. After routine processing, the specimens were embedded in paraffin for microtomy. Analysis of the results demonstrated that the haemostatic agents are effective in controlling hemorrhage; they stimulate osteogenesis, featuring a pattern of osseous tissue formation similar to the control pattern, although the amount of osseous trabeculae was superior, especially in the Gelfoam group in the periods of 7 and 14 days; 30 days after surgery, the delay in tissue healing in the control group in relation to the experimental groups started to decrease, and the control and experimental groups exhibited similar tissue repair after 45 days, when all the groups exhibited secondary osseous tissue.
\end{abstract}

Descriptors: Fibrin foam; Fibrin tissue adhesive; Osteogenesis; Rats; Tibia.

Resumo: Gelfoam ${ }^{\circledR}$ - uma esponja de gelatina biologicamente reabsorvível - tem por função coibir as hemorragias, promover o rompimento de plaquetas e sustentar a rede de fibrina. Beriplast $\mathrm{P}^{\circledast}$ - um composto de fibrinogênio-trombina - é usado na adesão de tecidos, consolidação de suturas e hemostasia. O objetivo deste estudo foi verificar histologicamente os efeitos de agentes hemostáticos na reparação óssea, os quais foram colocados em lojas cirúrgicas nas tíbias direita e esquerda de ratos jovens. Após os períodos de observação de 7, 14, 30 e 45 dias, segundo o protocolo bioético, os animais foram sacrificados, as tíbias foram removidas e fixadas em formalina a $10 \%$ e descalcificadas em partes iguais de soluções de ácido fórmico e citrato de sódio, para inclusão em parafina e microtomia. A análise dos resultados demonstrou que os agentes hemostáticos têm eficácia no controle hemorrágico; eles estimulam a osteogênese, provocando um padrão de formação de tecido ósseo semelhante ao padrão do grupo controle, embora a quantidade de trabéculas ósseas tenha sido superior principalmente no grupo do Gelfoam, nos períodos de 7 e 14 dias; após os 30 dias da cirurgia, o retardo na reparação tecidual do grupo controle em relação aos grupos experimentais começou a decrescer, tornando-se a reparação tecidual daquele semelhante à destes aos 45 dias, quando todos os grupos apresentaram tecido ósseo secundário.

Descritores: Espuma de fibrina; Adesivo tecidual de fibrina; Osteogênese; Ratos; Tíbia. 


\section{Introduction}

Fibrin sealers have been used in patients with either congenital or acquired blood dyscrasias as adjuncts for the control of bleeding that is associated with invasive surgical procedures. ${ }^{4,5,12,15,22,25-27}$

The presence of antibodies against coagulation factors or against platelets (immunothrombocytopenia) may impair the possibility to correct the defect in some patients. ${ }^{13,16}$ In patients that are prescribed oral anticoagulants, the correction of the coagulation defect may be hazardous. In some cases, there are adverse effects associated with the therapy used for correction of the defect. Frequent and large doses of prothrombin complex concentrate are an example of such therapies. The risk of postoperative bleeding can be diminished and the need for systemic replacement can be reduced or eliminated by enhancement of hemostasis at the site of the wound. . $^{13,15,16}$

Resorbable haemostatic sealers, when laid onto the site and immobilized by either sutures or simple compression, act as a scaffold where the blood clot will organize. Thus, the need for replacement therapy in patients with coagulation alterations can be reduced through sutures or even through the use of a fibrin haemostatic agent. ${ }^{15,16}$

Gelfoam, a gelatin-based sponge, is insoluble in water and biologically resorbable. Its function is to restrict blood vessel hemorrhage whose homeostasis has not been obtained by means of ligatures and sutures, provide platelet rupture, and support fibrin threads. ${ }^{7}$ It can be used solely or associated with thrombin in oral surgeries. ${ }^{8}$

A large number of studies have demonstrated that this material initially provokes an inflammatory response, though with no long-term side effects on osseous formation if completely removed. , $11,14,21^{2}$

Beriplast - a fibrin sealer compounded by fibrinogen, factor XIII and thrombin, all isolated from human plasma and lyophilized - has an effect based on the final stage of coagulation. ${ }^{16,24}$ Its major components, human fibrinogen and thrombin, lead to the formation of a fibrin clot that is stable and insoluble in the presence of FXIII and calcium. ${ }^{6,18,24}$ Beriplast affords tissue healing as it is degraded in the organism by the action of fibrinolysis and phagocytosis, leaving no residues and decreasing tissue reactions.
Advancements in surgery, particularly in microsurgery, are influenced by the development of surgical tissue repairs. Fibrin sealer has brought a new dimension to tissue adhesion as an effective agent for the treatment of soft tissue wounds. At times, the combination of suture and tissue sealers has demonstrated the best results. ${ }^{19}$

Many studies carried out both in the periapical region ${ }^{2,23,28,29}$ and in osseous tissue $e^{1,8-11,14,20}$ have demonstrated that if the haemostatic agents are inadvertently left in the surgical site they can induce an inflammatory process and affect tissue repair. ${ }^{2,3,9,28}$

The objective of this study was to assess the effects of haemostatic agents on osseous repair in rat tibia, aiming to observe the presence of inflammatory cells and osseous tissue formation.

\section{Material and Methods}

Thirty-two rats (Rattus norvegicus albinus, Holtzman) with body weight around $120 \mathrm{~g}$, kept in individual cages under climatized environment were used in this study. The animals were divided into three groups: control, experimental Beriplast ${ }^{\circledR}$ (Aventis Behring Ltda., São Paulo, SP, Brazil), and experimental Gelfoam ${ }^{\circledR}$ (Pharmacia Brasil Ltda., São Paulo, SP, Brazil). Assigning 5 rats to the experimental groups and 3 to the control group, the animals were killed 7, 14, 30 and 45 days after surgery. In order to perform the surgical procedures, all the animals were anesthetized with an intramuscular injection of $10 \%$ Ketamine and 2\% Xilazine Hydrochloride (Vibac do Brasil, São Paulo, SP, Brazil), at a dosage of $0.08 \mathrm{ml}$ and $0.04 \mathrm{ml}$ per $100 \mathrm{~g}$ of body weight, respectively.

After trichotomy and antisepsis of both right and left limbs with 70\% ethanol, the medial surface of each tibia was exposed and a bone cavity from cortical to marrow was performed with sterilized handpiece and $\# \frac{1}{2}$ carbide round bur, $5 \mathrm{~mm}$ distal to the tibial tubercle.

The osseous defect was filled with Beriplast in the right tibia and with Gelfoam - which was removed after 10 minutes - in the left tibia. The incisions were sutured with Vicryl suture (Poligalactine 910, Johnson \& Johnson Produtos Profissionais Ltda., São José dos Campos, SP, Brazil).

In the control group, the animals went through 
the same procedures used for those of the experimental groups, and the osseous defect was irrigated with saline solution.

In the periods of 7, 14, 30 and 45 days after surgery, the animals were killed with an intraperitoneal injection of chloral hydrate overdose and the tibiae were removed and fixed in $10 \%$ formalin solution for 48 hours and decalcified in a solution of sodium citrate and formic acid in equal parts. ${ }^{17}$ After decalcification, the specimens were washed during 24 hours and dehydrated, cleared and embedded in paraffin. In order to carry out analysis under light microscopy, semi-serial $6 \mu \mathrm{m}$-thick sections were obtained and stained with hematoxylin and eosin.

\section{Results}

The presence of inflammatory cells and the formation of connective tissue and osseous tissue in the rat tibiae were considered in the histological analysis of the specimens of the Control, Beriplast and Gelfoam groups.

\section{Seven-day postoperative period}

The Control group features active osseous formation, and the osseous defect shows connective tissue surrounding small and sparse neoformed osseous trabeculae (Figure 1). In the Beriplast group, the osseous defect shows immature osseous trabeculae and the presence of material residues surrounded by a thin layer of connective tissue containing few in-

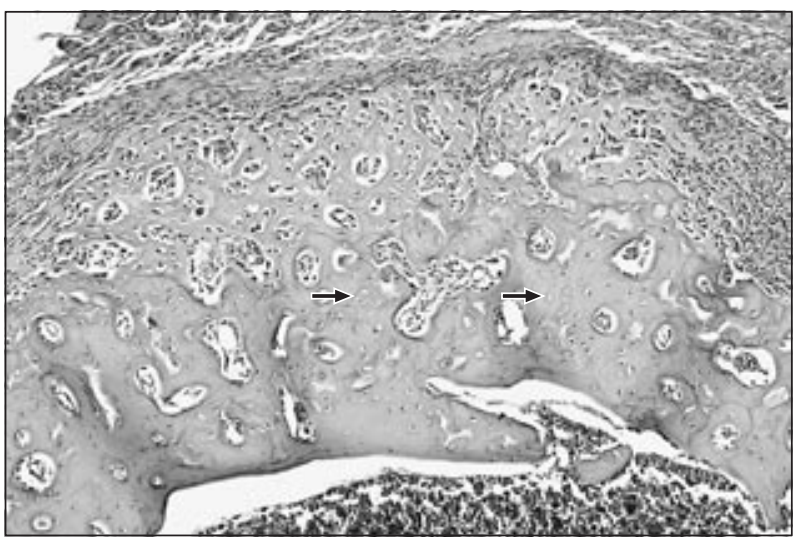

Figure 1 - Control group (7 days) - The osseous defect is filled with connective tissue and neoformed osseous trabeculae (arrows). H.E. 100 X. flammatory cells (Figure 2). In the Gelfoam group, the defect shows numerous neoformed osseous trabeculae, surrounding small residues of remaining material (Figure 3). The presence of inflammatory cells and some macrophages is noticed.

\section{Fourteen-day postoperative period}

The Control group's osseous defects feature thicker immature osseous trabeculae than in the former period surrounding wide medullar spaces (Figure 4). In the Beriplast group, the osseous defect is partially filled with numerous immature osseous trabeculae delineating wide medullar spaces (Figure 5). In few specimens, the presence of material residues is also observed. In

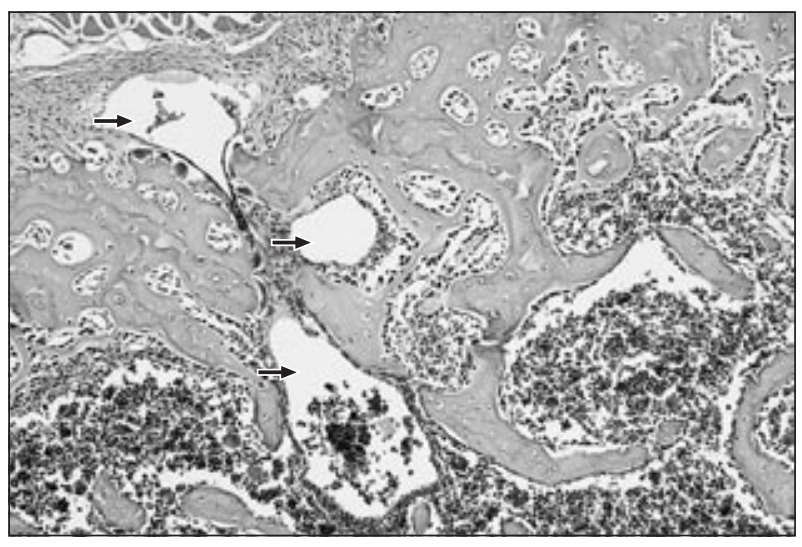

Figure 2 - Beriplast group (7 days) - Neoformed osseous trabeculae. Note the presence of material residues (arrows) H.E. $100 \mathrm{X}$.

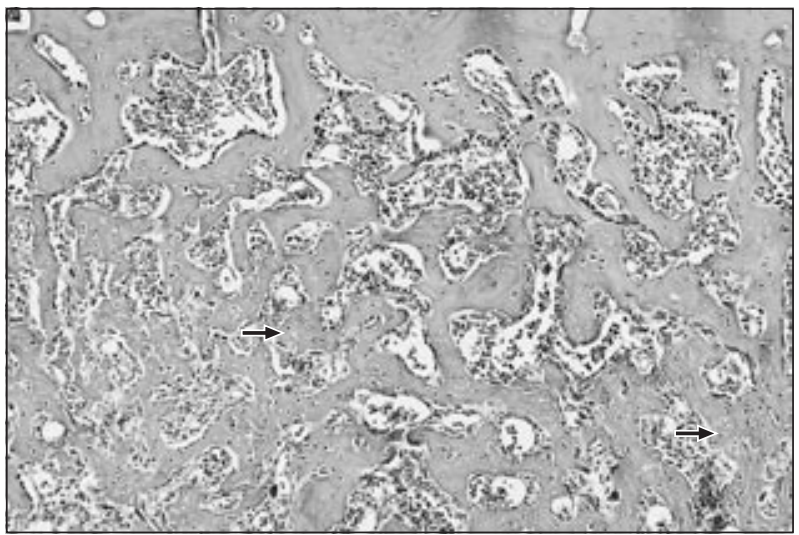

Figure 3 - Gelfoam group (7 days) - Numerous neoformed osseous trabeculae are filling the osseous defect (arrows). H.E. $100 \mathrm{X}$. 


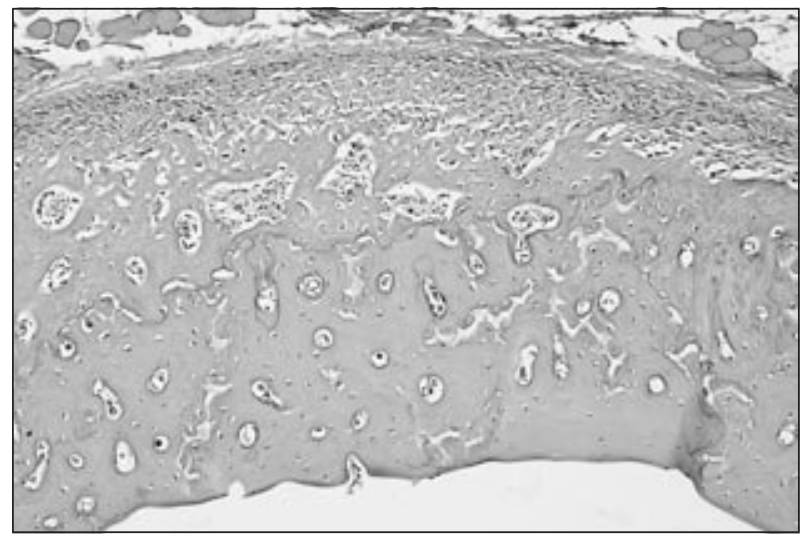

Figure 4 - Control group (14 days) - Neoformed osseous trabeculae and large medullar spaces are observed. H.E. $100 \mathrm{x}$.

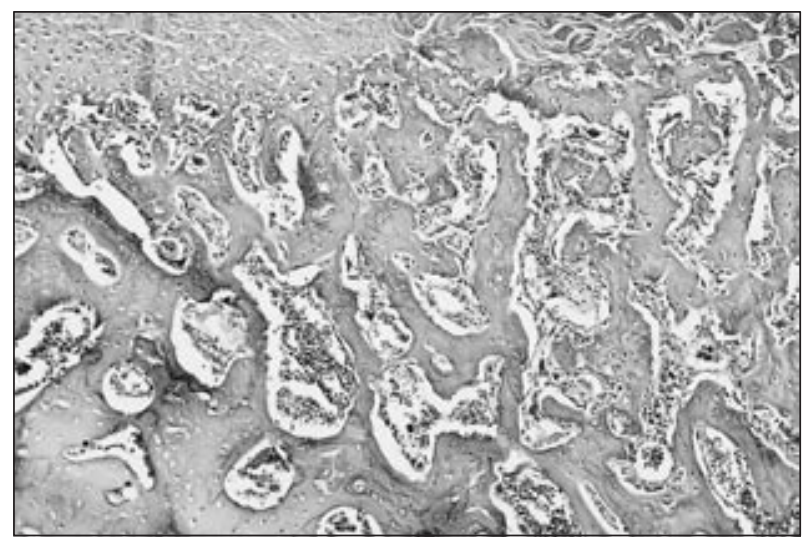

Figure 5 - Beriplast group (14 days) - The osseous defect is filled with numerous immature osseous trabeculae. H.E. $100 \mathrm{X}$.

the Gelfoam group, the osseous defect no longer presents material residues, the amount of osseous tissue formed is larger and the maturation level is more advanced than in the former period as well as compared to the Control and Beriplast groups. It is also possible to observe wide medullar spaces (Figure 6). The aspect of the osseous repair observed in the specimens suggests that osteogenesis in the Gelfoam group is more intense in the 7- and 14-day postoperative periods.

\section{Thirty-day postoperative period}

The Control, Beriplast (Figure 7) and Gelfoam groups feature an osseous defect filled by more compact osseous tissue when compared to the former

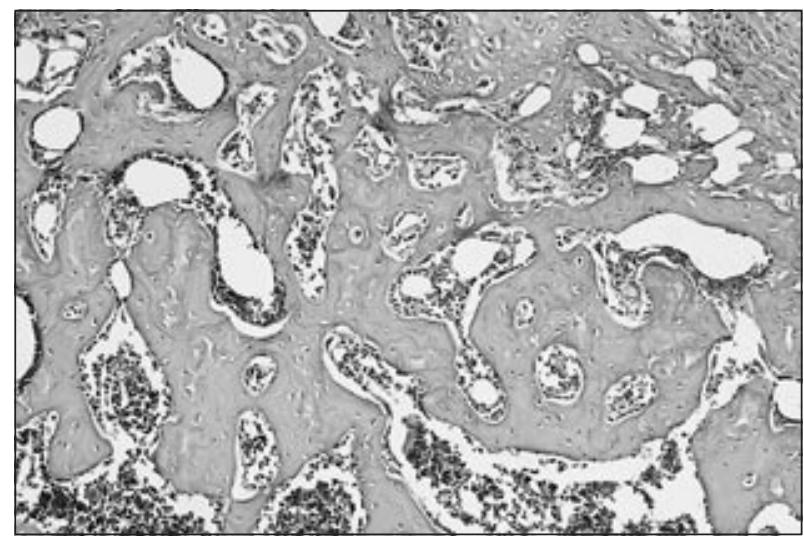

Figure 6 - Gelfoam group (14 days) - The osseous trabeculae filling the defect are larger and the maturation level is more advanced in comparison to the Beriplast and Control groups. H.E. $100 \mathrm{X}$.

periods, outlined by a formerly formed bone adjacent to the bone cortical, delineating small and defined medullar spaces.

\section{Forty-five-day postoperative period}

Forty-five days after surgery, the appearance of the surgical sites was basically similar to that of the 30-day specimens. The osseous defects were completely repaired with compact bone and the periosteum was well developed (Figure 8).

\section{Discussion}

The use of haemostatic/antifibrinolytic materials plays a role in forming fibrin and causing the retraction of the blood clot, thus affecting the repair process. ${ }^{4,5,12,15,22,25-27}$ This process is divided into 3 phases: exudative, where fibrin development occurs; proliferative, which is characterized by the occurrence of fibroblastic and capillary proliferation; and reparative, evidenced by collagen synthesis and osteogenesis. ${ }^{1}$ Studies have demonstrated that fibrin exerts at least two functions on a wound repair: homeostasis and stimulus to the proliferation of perivascular fibroblasts. ${ }^{16}$

The assessment of experimental osseous defect repair in rat tibia has demonstrated that distinct osseous reactions happen depending on the haemostatic agent used and if it was either removed or left in the surgical site. It has been shown that osteogenesis in the Gelfoam group occurs faster ${ }^{11}$ when compared to that observed in the Control and Beriplast groups. 


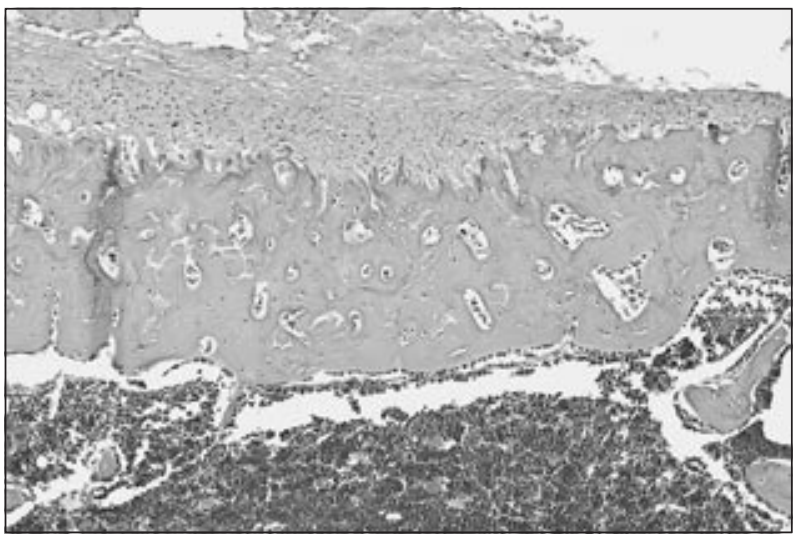

Figure 7 - Beriplast group (30 days) - The osseous defect is filled with compact osseous tissue. Note the presence of defined medullar spaces. H.E. $100 \mathrm{X}$.

The results of the present study showed that the use of Beriplast and Gelfoam in osseous defects favored blood clot organization as well as osseous repair, mainly in the initial 7- and 14-day postoperative periods, while in the subsequent periods osteogenesis was similar in the control and experimental groups. The sequence of events in rat tibia osseous repair was similar to that observed by other authors. ${ }^{8,10,11,14,21}$

Seven days after surgery, the control group featured an osseous defect with connective tissue surrounding small and sparse neoformed osseous trabeculae, and filled with signs of osteogenesis organization and initiation, which occurred increasingly up to the 45-day postoperative period, when the surgical site was found filled with compact osseous tissue.

Although the haemostatic agents were temporarily kept in the osseous defects - a situation planned to create conditions similar to those of patients with blood dyscrasias - the results for the experimental groups showed that they did not interfere in the organization of the clot and in the osteogenesis of the tibiae when compared to the events that occurred in the Control group. ${ }^{11,20}$ Thus, small amounts of residual haemostatic agent material were observed in some specimens 7 and 14 days after surgery, but they neither induced an inflammatory response $\mathrm{e}^{8,9,14}$ nor harmed the osseous repair in the 30- and 45day postoperative periods as they were resorbed.

Larger amounts of osseous trabeculae than those found in the Control group could be observed 7 days

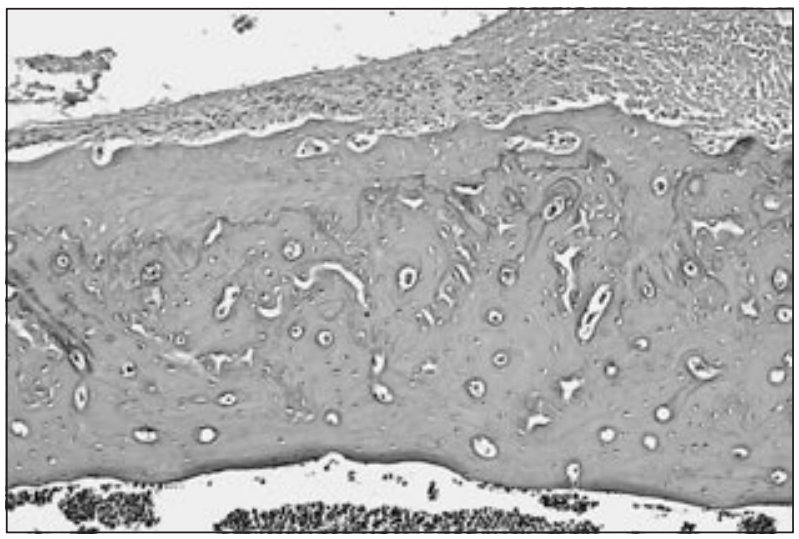

Figure 8 - Gelfoam group (45 days) - The osseous defect is completely repaired with compact bone. Note that the periosteum is well developed. H.E. 100 X.

after surgery in the experimental groups, but they were more evident after 14 days in the Gelfoam group.

In the subsequent observation periods - 30 and 45 days after surgery - this osteogenesis difference did not occur so evidently. The osseous defects created in rat tibiae were found to be completely repaired by compact osseous tissue in the final period of the present study in all groups. These findings confirm those obtained by other authors. ${ }^{9,11}$

The results indicate that the haemostatic agents assessed in this study can be used in oral surgeries; however, there is a strong recommendation for the total removal of the material 5 to 10 minutes after application, because the presence of material residues can induce an inflammatory response.

Further comparative studies between the haemostatic agents tested are necessary to clarify whether the performance of Beriplast and Gelfoam in human osseous defects is similar to that observed in rat tibiae.

\section{Conclusions}

The Beriplast and Gelfoam haemostatic agents were effective in controlling hemorrhage and stimulating osteogenesis in osseous defects in the periods assessed. Apparently, Gelfoam provided a more intense stimulation of osseous repair in the initial periods.

The presence of residual material induced a low inflammatory response, but it did not harm osteogenesis. 


\section{References}

1. Alves-Rezende MCR, Okamoto T. Effects of fibrin adhesive material (Tissucol) on alveolar healing in rats under stress. Braz Dent J. 1997;8(1):13-9.

2. Arens DE, Adams WR, De Castro RA. Endodontic surgery. Philadelphia: Harper \& Row; 1981.

3. Bhaskar SN. Oral surgery - oral pathology conference No. 17, Walter Reed Army Medical Center. Periapical lesions - types, incidence, and clinical features. Oral Surg Oral Med Oral Pathol. 1966;21(5):657-71.

4. Blatt PM, White GC $2^{\text {nd }}$, McMillan CW, Webster WP. Failure of activated prothrombin complex concentrates in a hemophiliac with an anti-factor VIII antibody. JAMA. 1984;251(1):67.

5. Brown B, Steed DL, Webster MW, Makaroun MS, Spero JA, Bontempo FA et al. General surgery in adult hemophiliacs. Surgery. 1986;99(2):154-9.

6. Chang H, Wu GJ, Perng WL, Hwang FY, Hung CR. Effects of fibrin glue on hemostasis. J Formos Med Assoc. 1992;91(6):601-7.

7. Costich ER, Hayward JR. Hemorrhage: its prevention and therapeutic control. Dent Clin North Am. 1958;2:195-210.

8. Guralnick WC, Berg L. Gelfoam in oral surgery: a report of two hundred and fifty cases. Oral Surg Oral Med Oral Pathol. 1948;1:632-9.

9. Haasch GC, Gerstein H, Austin BP. Effects of two hemostatic agents on osseous healing. J Endod. 1989;15(7):310-4.

10. Howard TC, Kelley RR. The effect of bone wax on the healing of experimental rat tibial lesions. Clin Orthop Relat Res. 1969;63:226-32.

11. Ibarrola JL, Bjorenson JE, Austin BP, Gerstein H. Osseous reaction to three hemostatic agents. J Endod. 1985;11(2):7583.

12. Iwata H, Oishi $Y$, Itoh A, Ishiguro N, Yamaga H, Miyamoto $\mathrm{N}$ et al. Surgical excision of Hemophilic pseudotumor of the ilium. Clin Orthop Relat Res. 1992;(284):234-8.

13. Kasper CK. Thromboembolic complications. Thromb Diath Haemorrh. 1975;33:640-4.

14. Laskin JL, Lucas WJ, Davis WM Jr. The effects of granular gelatin preparation on the healing of experimental bone defects. Oral Surg Oral Med Oral Pathol. 1981;52(1):23-7.

15. Lozier JN, Santagostino E, Kasper CK, Teitel JM, Hay CRM. Use of porcine factor VIII for surgical procedures in hemophilia A patients with inhibitors. Semin Hematol. 1993;30(2 Suppl 1):10-21.

16. Martinowitz U, Schulman S, Horoszowski H, Heim M. Role of fibrin sealants in surgical procedures on patients with he- mostatic disorders. Clin Orthop Relat Res. 1996;(328):6575.

17. Morse A. Formic acid sodium citrate decalcification and butyl alcohol dehydration of teeth and bones for sectioning in paraffin. J Dent Res. 1945;24(3/4):143-53.

18. Mosher DF. Cross-linking of fibronectin to collagenous proteins. Mol Cell Biochem. 1984;58(1):63-8.

19. Mouritzen C, Drömer M, Keinecke HO. The effect of fibrin glueing to seal bronchial and alveolar leakages after pulmonary resections and decortications. Eur J Cardiothorac Surg. 1993;7(2):75-80.

20. Okamoto T, Alves-Rezende MC, Buscariolo IA, Okamoto AC, Mendes VS, Garcia-Jr IR. Implante da associação esponja de fibrina $\left(\right.$ Fibrinol $^{\circledR}$ )/adesivo fibrínico (Tissucol ${ }^{\circledR}$ ) em cavidade cirúrgica preparada em tíbia de rato. Estudo histológico. Rev Odontol Univ São Paulo. 1996;10(1):33-7.

21. Olson RA, Roberts DL, Osbon DB. A comparative study of polylactic acid, Gelfoam, and Surgicel in healing extraction sites. Oral Surg Oral Med Oral Pathol. 1982;53(5):441-9.

22. Parry DH, Bloom AL. Failure of factor VIII inhibitor bypassing activity (Feiba) to secure haemostasis in haemophilic patients with antibodies. J Clin Pathol. 1978;31(11):1102-5.

23. Selden HS. Bone wax as an effective hemostat in periapical surgery. Oral Surg Oral Med Oral Pathol. 1970;29(2):2624.

24. Shen L, Lorand L. Contribution of fibrin stabilization to clot strength. Supplementation of factor XIII-deficient plasma with the purified zymogen. J Clin Invest. 1983;71(5):1336-41.

25. Sindet-Pedersen S. Haemostasis in oral sugery - the possible pathogenetic implications of oral fibrinolysis on bleeding. Experimental and clinical studies of the haemostatic balance in the oral cavity, with particular reference to patients with acquired and congenital defects of the coagulation system. Dan Med Bull. 1991;38(6):427-43.

26. Sjamsoedin LJ, Heijnen L, Mauser-Bunschoten EP, van Geijlswijk JL, van Houwelingen $H$, van Asten $P$ et al. The effect of activated prothrombin-complex concentrate (Feiba) on joint and muscle bleeding in patients with hemophilia $\mathrm{A}$ and antibodies to factor VIII. A double-blind clinical trial. N Engl J Med. 1981;305(13):717-21.

27. Spivack AR. Orthopedic and medical treatment of patients with hemophilia. Arch Intern Med. 1983;143(7):1431-3.

28. Weine FS. Endodontic therapy. St. Louis: CV Mosby; 1982.

29. Yusuf $H$. The significance of the presence of foreign material periapically as a cause of failure of root treatment. Oral Surg Oral Med Oral Pathol. 1982;54(5):566-74. 